\title{
CONTROL SYSTEM SIMULATION BY MODULAR UNINTERRUPTIBLE POWER SUPPLY UNIT WITH ADAPTIVE REGULATION FUNCTION
}

\author{
Andriy Palamar
}

\section{Ternopil Ivan Puluj National Technical University, Ternopil, Ukraine}

\begin{abstract}
Summary. The article deals with the problem of simulation modeling of rectifiers control system for the modular uninterruptible DC power supply unit in order to increase energy efficiency of its operation. This paper proposes a control logic algorithm to manage the process of switching the power modules of the UPS in the adaptive correction mode of the system nominal power. The main idea of the method is to implement the process of turning on/off the rectifiers to achieve the optimal value of their load factor and maintain its level in a certain set optimal range. Control system block diagram of the modular uninterruptible power supply is provided. Besides the central control module rectifiers, control units are introduced. They are responsible for realization of their on/off switching process and carries out control of their condition. In order to study the effectiveness of the developed algorithm, a computer model is created to describe the control logic of rectifiers management. To implement the simulation model, the software environment for visual modeling Simulink Matlab and the mathematical apparatus of the Stateflow component library are used. The developed simulation model has been tested and the simulation results are given in the research. The application of the developed algorithm allowed to increase the efficiency of the uninterruptible power supply by adjusting the load factor of the UPS in real time within a predetermined optimal range of values. The simulation results demonstrate the effectiveness of the developed simulation model of the control system in different operating modes.
\end{abstract}

Key words: control system, uninterruptible power supply unit, simulation modeling.

Statement of the problem. When designing continuous power supply systems for industrial facilities [1] modular uninterruptible power supply units (UPS) [2] and Power Arrays [3] are increasingly used. These are the system of parallel connected units of power electronics, batteries and control modules which provide their customers with electrical power even when one of the modules goes down. Such systems possess a certain degree of excessiveness $(\mathrm{N}+\mathrm{M}$ type of redundancy) that allows to replace the defective unit using the method hot swapping, that is without turning off entire equipment [4].

To power the equipment being used in telecommunication and computer systems modular DC UPS [5] units are most common among others. Their advantage is the absence of DC/AC - AC/DC transformation, which allows to increase the efficiency factor of UPS units. The main power components of such systems are rectifiers which transform direct current into alternating current thus providing power to equipment.

Telecommunication equipment such as for instance mobile base stations are characterized by random nature of power consumption. The range of energy consumption for such equipment is within large extremes [6] and depends on the number of parties connected simultaneously, who transmit or receive information.

When designing UPS units to power telecommunication equipment the number of power modules is determined by its peak capacity. Besides, in order to provide a higher level of error tolerance excessive modules come in place. But peak traffic is not a commonplace 
under normal operating conditions, so usually the working capacity of UPS units remain low (approximately 30\%) [7]. The fact of low output load of a UPS unit causes significant decrease of general efficiency factor of entire power supply system as every single power module has certain degree of open circuit operation loss value and this loss decreases when load coefficient increases [8].

Evaluation of known experimental studies. The study of scientific works [8-10] proves that modern UPS units demand for high reliability and error tolerance which can be achieved by modular architecture and redundancy protection. Alongside with that, to increase UPS unit efficiency rate we need to decrease power module redundancy and increase their operating load in order to minimize open circuit loss within the power supply system. Contradictions arise as endeavors to boost UPS unit reliability leads to redundancy of power modules, hence decreasing their efficiency.

Plethora of scientific researches dedicated to the development of energy efficiency enhancement of UPS devices proves that mentioned problems are important today.

Comparative analyses conducted in works [10,11] shows that modular DC uninterruptible power supply has the best reliability and energy efficiency.

Works [7, 8] state that in order to minimize losses and maximize energy efficiency one needs to reduce redundancy through the use of adaptive modular architecture of UPS, which will allow to enhance power supply infrastructure as the load increases.

The work [12] offers a model for evaluation of power supply efficiency. Which takes into account the rapid fall of efficiency under minimal loads. It is shown that significant energy losses occur due to open circuit losses in power supply components. In order to increase efficiency, it is reasonable to apply the technique of adaptive selection of UPS power modules capacity, and to make this work, it is necessary to develop the algorithm for intelligent control system. But this algorithm has not been created.

Objective. The objective of this research is to simulate the operation of intelligent control system for modular DC UPS unit to obtain optimal load coefficient value of power modules, which will provide the opportunity to get optimal correlation of efficiency and error tolerance using the technique of power modules output adaptive control.

Statement of the task. In order to design and test the operation of electrical facility control systems with optimal performance (taking into account the correlation of reliability, efficiency and quality), due to their complexity and high experimental cost, we need to use simulation of accurate models. Thus, to meet the research objective, it is necessary to develop and study the simulation model of control logic which would allow to control a certain number of UPS power modules by switching method with no dependence on their load value.

Operational algorithm of the system. The main idea of technique for adaptive selection of power modules lies in realization of switching on/off control algorithm to obtain optimal load coefficient value and keeping it within set range. To implement this algorithm, it is necessary to choose appropriate hardware within UPS control system. Apart from central control module, which is responsible for monitoring and controlling the entire system, it is necessary to include rectifier control unit as well. Structural scheme of control system for modular uninterruptible power supply, which this article deals with, is shown on Figure 1. 


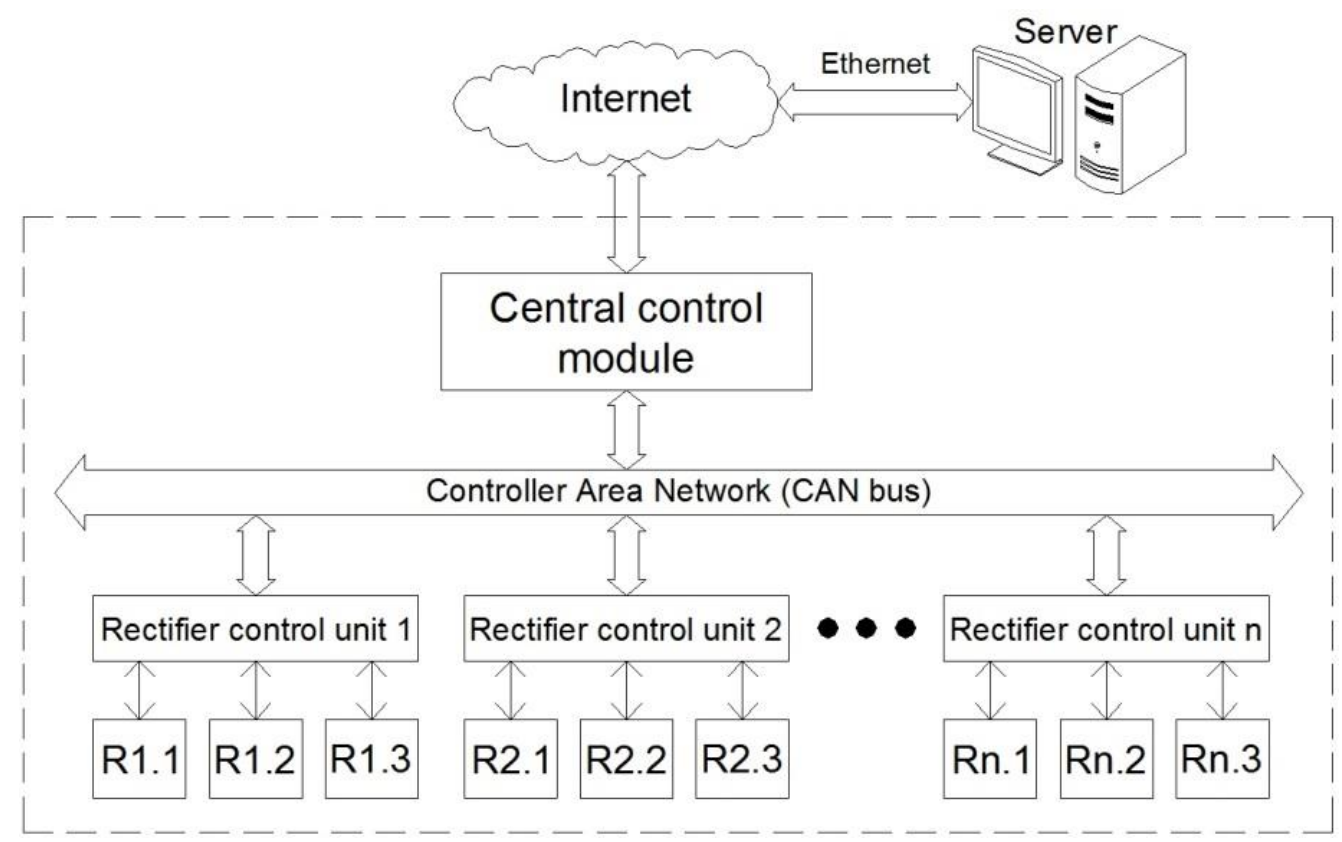

Figure 1. Structural scheme of control system for modular uninterruptible power supply

Central control module (CCM), which is described in works [13-15], is responsible for the process of monitoring the parameters of the UPS subsystems, manages all modes of its operation, periodically saves received data in non-volatile memory and transfers them to the server. Rectifier control unit (RCU) is responsible for the process of their commutation and controls their operational conditions. For instance, rectifiers are being checked for overheating and overloading conditions. CAN interface was selected for data exchange between CCM and RCU. Due to its high reliability it is the best option to create distributional control system which is used in this work.

Control system operating algorithm works in the following way. On the first stage current values in battery circuits are evaluated, load circuit current and output current values. Then data on rectifiers' condition is read and the number of rectifiers which are in the operating state is determined. On the next stage the UPS consumed power is evaluated and, based on this, rectifier load coefficient is calculated by the formula:

$$
K_{\text {load }}=\frac{P_{\text {cons }}}{N \cdot P_{\text {nom }}}
$$

where $K_{\text {load }}$ is the rectifier load coefficient;

$N$ - number of rectifiers in the operating condition;

$P_{\text {nom }}$ - nominal output of a single rectifier;

$P_{c o n s}-$ real consumption power that is calculated by the formula:

$$
P_{\text {cons }}=\left(I_{\text {load }}+\sum_{i=1}^{m} I_{B A T i}\right) \cdot U_{\text {out }}
$$

where $I_{\text {load }}$ is current in the load circuit;

$I_{B A T i}$-current in circuit $i$ of $\mathrm{AB}$ group;

$m$ - number of AB groups;

$U_{\text {out }}$ - UPS output voltage. 
Thus, substituting equation (2) into (1) will result in the following formula for calculation of load coefficient:

$$
K_{\text {load }}=\frac{\left(I_{\text {load }}+\sum_{i=1}^{m} I_{\text {BATi }}\right) \cdot U_{\text {out }}}{N \cdot P_{\text {nom }}} .
$$

Current rectifier load coefficient value $K_{\text {load }}$ is compared with low threshold level $K_{\min }$ and high threshold level $K_{\max }$, which are determined experimentally and stored as parameters in non-volatile memory of UPS central control module.

In case if value $K_{\text {load }}$ is more than threshold level $K_{\max }\left(K_{\text {load }}<K_{\max }\right)$, the calculation of predicted rectifier load coefficient value is performed using the formula:

$$
K_{\text {pred }}=\frac{\left(I_{\text {load }}+\sum_{i=1}^{m} I_{B A T i}\right) \cdot U_{\text {out }}}{\left(N_{\text {op }}+j\right) \cdot P_{\text {nom }}},
$$

where $K_{\text {pred }}$ is rectifier load coefficient value;

$j=\left\{1,2, \ldots,\left(N_{\text {all }}-N_{o p}\right)\right\}-$ number of loop iterations;

$N_{\text {all }}$ - overall number of working rectifiers;

$N_{o p}$ - number of operating rectifiers.

Coefficient $j$ is changed upwards in every iteration cycle per 1 unit beginning with initial value which equals 1 unless condition $K_{\text {pred }} \geq\left(K_{\max }+H_{\max }\right)$ is satisfied, where $H_{\max }$ is the value of hysteresis effect of the highest threshold level of rectifier load coefficient, which is determined experimentally and is sored as parameter in non-volatile memory of UPS central control module.

If $K_{\text {load }}<K_{\min }$, then calculation for predicted rectifier load coefficient value $K_{\text {pred }}$ is performed by the formula:

$$
K_{\text {pred }}=\frac{\left(I_{\text {load }}+\sum_{i=1}^{m} I_{B A T i}\right) \cdot U_{o u t}}{\left(N_{o p}-j\right) \cdot P_{\text {nom }}}
$$

In this case the coefficient $j$ decreases per 1 unit in every iteration cycle beginning with initial value which equals 1 , until the condition $K_{\text {pred }} \geq\left(K_{\min }+H_{\min }\right)$ is satisfied, where $H_{\min }$ is the value of hysteresis effect of the lowest threshold level of rectifier load coefficient.

In the result of performed cycle above, predicted value of rectifier numbers will be obtained $N=N_{o p(t+1)}$, which should remain in the operating mode in order their load coefficient is within predetermined optimal range $K_{\min }<K_{\text {load }}<K_{\max }$.

After that, a central control module subroutine call is performed, which sends instruction to the rectifier control unit to switch on the necessary number of power modules $N=N_{o p(t+1)}$ using the CAN bus.

Simulation model. To design model in this research we used Matlab Simulink software environment using component libraries Stateflow. Simulation model for modular UPS control system in the mode of rectifier adaptive load control shown in Figure 2 employs the following components:

1. Array of input signals:

- $U_{\text {out }}$ - UPS output voltage;

- $\quad I_{\text {load }}$ - load current;

- $I_{\text {bat } 1}, I_{\text {bat } 2}$ - currents flowing in battery circuits.

2. Control systems input parameters:

- $K_{\max }, K_{\min }-$ high and low rectifier load coefficient threshold levels, their values being 0.8 and 0.5 correspondingly in this model; 
- $\quad P_{\text {nom }}-$ nominal capacity of a single power unit which in this UPS equals $3 \mathrm{kWt}$. All in all our system employs 6 rectifiers.

3. Control Logic unit, which contains implementation of control logic.

4. Result unit, designed for displaying results of simulation.

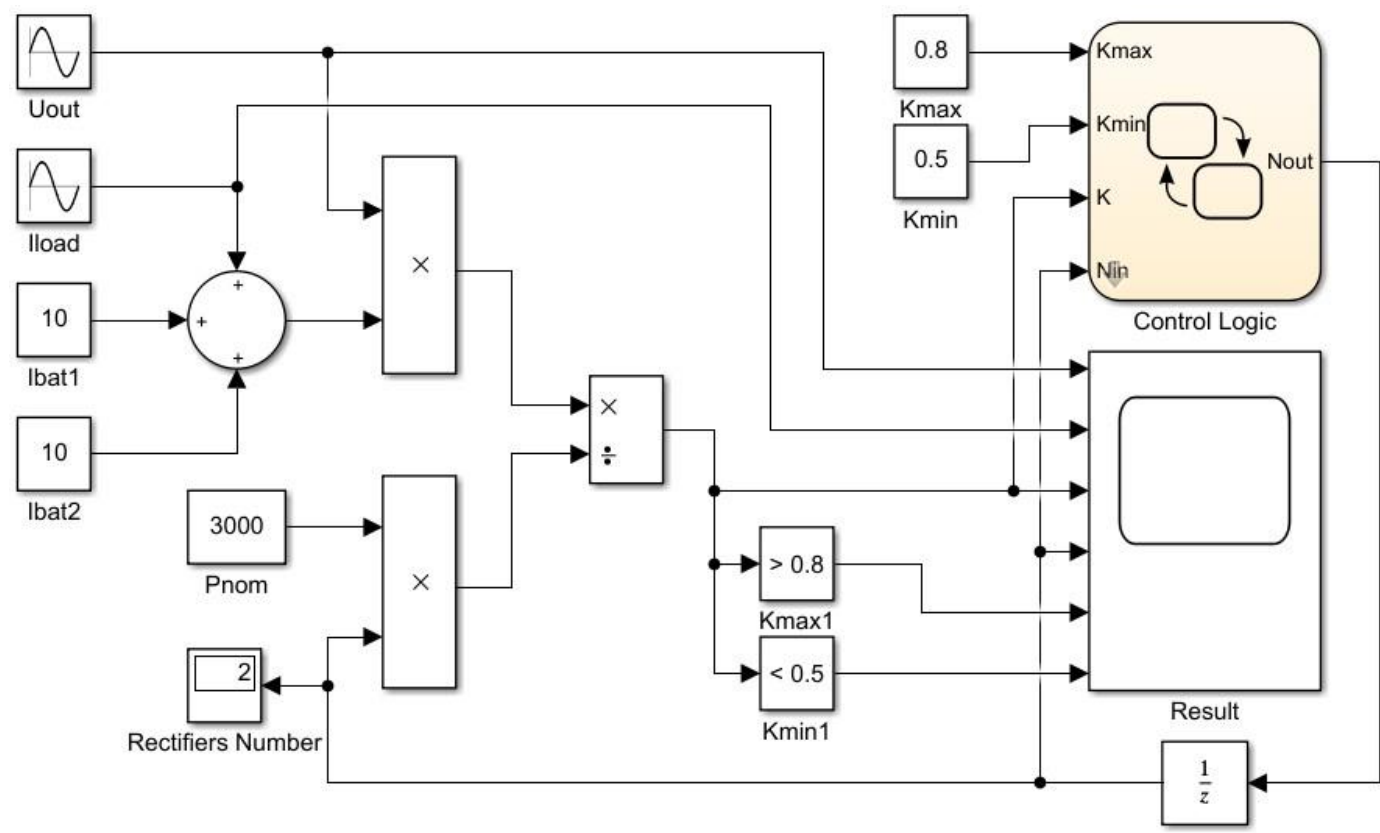

Figure 2. Simulation model of the modular UPS control system in the adaptive adjustment mode of rectifiers loading

Unit Control Logic (Figure 3), which is designed by using Stateflow instrument, implements algorithm for calculation of necessary number of rectifiers required for their load coefficient to be within $K_{\min }<K_{\text {load }}<K_{\max }$ range value.

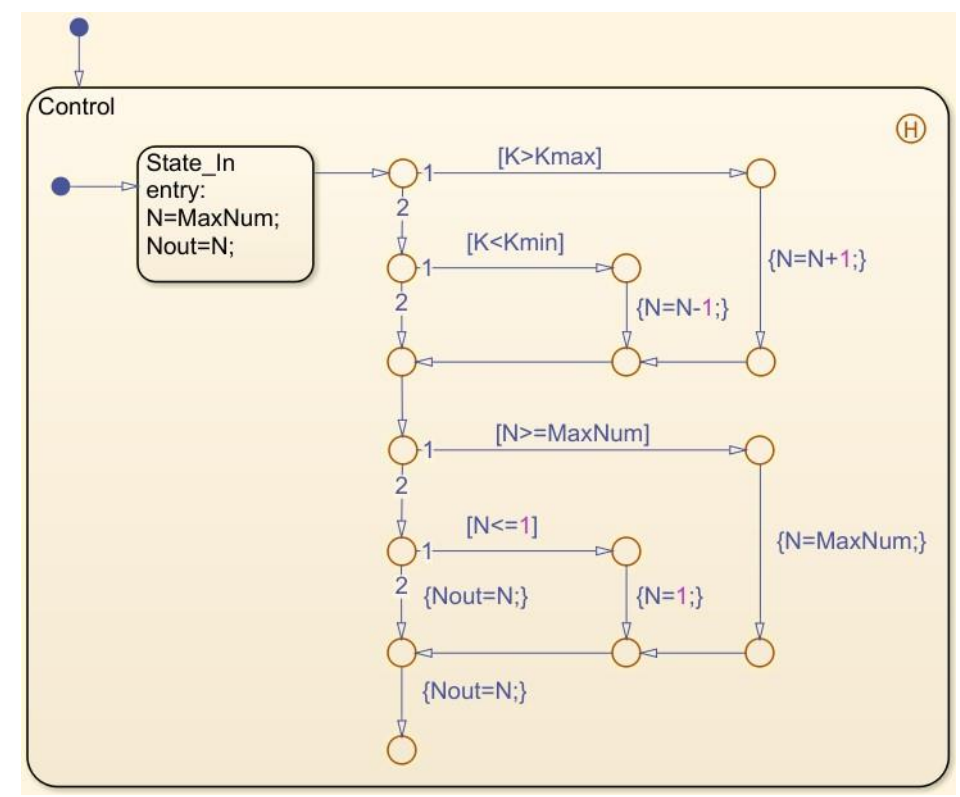

Figure 3. Simulation model of the algorithm for calculating the required number of rectifiers 
Simulation results. For given configuration of UPS control system simulation has been performed, obtained results shown in Figure 4 in the form of oscilloscope pattern for Result unit. Figure $4 \mathrm{a}$ and $4 \mathrm{~b}$ shows change dependencies of output voltage and current from time in the load circuit, which cause the change of rectifier load coefficient (Figure $4 \mathrm{c}$ ). The dynamics of change of number of operating power modules is shown on Figure $4 \mathrm{~d}$.

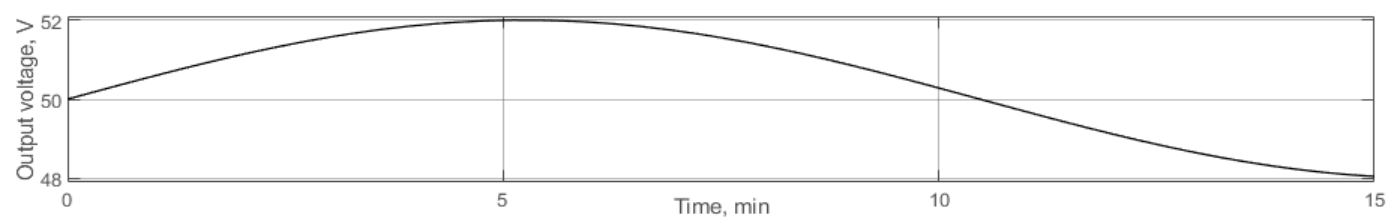

a)

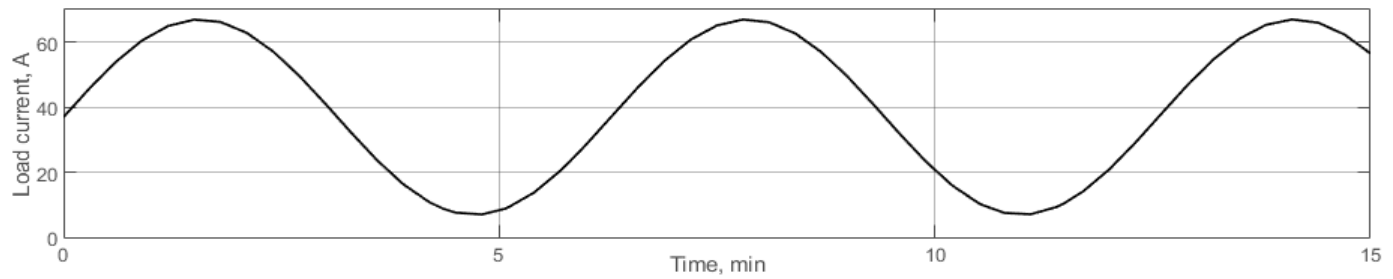

b)
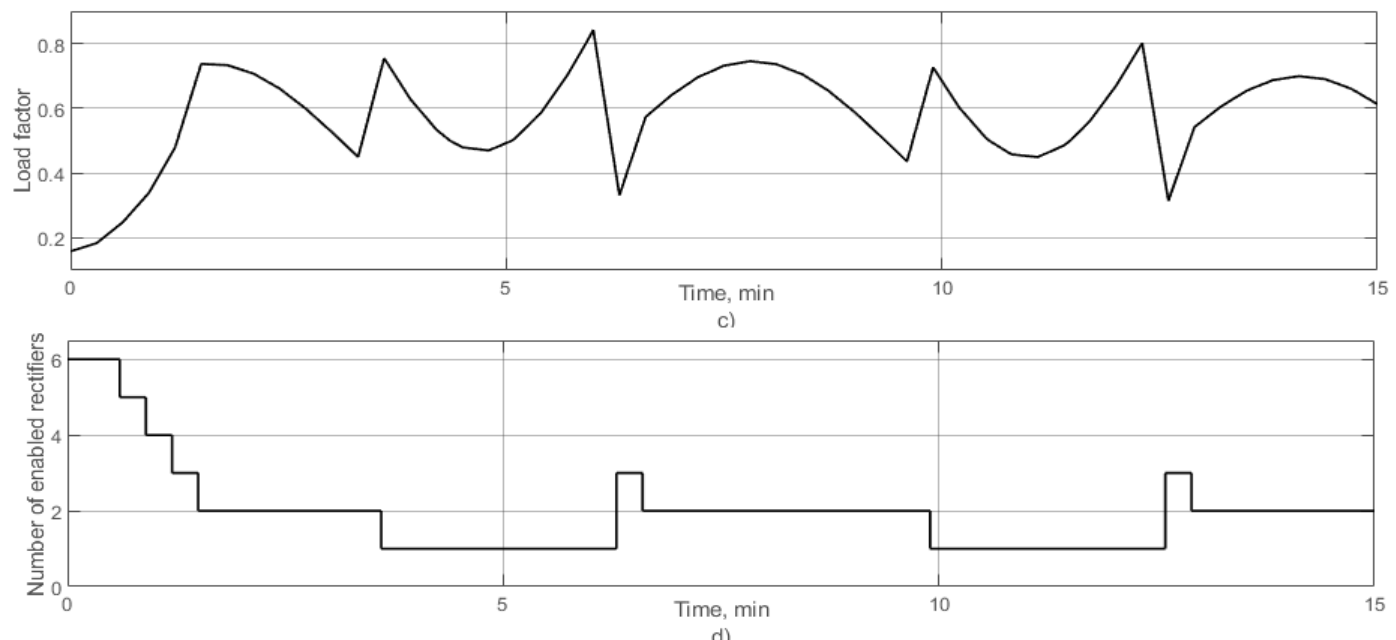

d)

Figure 4. Simulation results of the modular UPS control system in the adaptive adjustment mode of rectifiers loading

As results show (Figure $4 \mathrm{c}$ ), rectifier load coefficient is within the set range of threshold values $(0.5 \ldots 0.8)$ apart from several peak values. Power modules switching is performed in such a way that at least one of the modules must stay in operational mode.

Conclusions. In the result of simulation modelling an algorithm for control system operation of modular uninterruptible power supply unit has been worked out. Method of adaptive adjustment of rectifier load level within predetermined optimal values range has been designed in real time. Modelling results showed the effectiveness of designed simulation model of control system with different input electrical parameters. Obtained findings were used by implementation of developed algorithm in real control system of modular uninterruptible power supply unit.

\section{References}

1. Andriychuk V., Filyuk Y. Autonomous power supply system for outdoor illumination of residential areas in the territory of Ukraine. Scientific Journal of TNTU. 2018. Vol. 89. No. 1. P. 113-121. https://doi.org/10.33108/visnyk_tntu2018.01.113 
2. Grigorash O. V., Denisenko E. A., Chumak M. S. Sintez modulnykh sistem besperebojnogo ehlektrosnabzheniya povyshennoj nadyozhnosti. Politematicheskij setevoj ehlektronnyj nauchnyj zhurnal Kubanskogo gosudarstvennogo agrarnogo universiteta. 2015. Vol. 108. No. 4. P. 1-14. [In Russian].

3. Dulepov D. E., Tyundina T. E. Kachestvo i nadezhnost ehlektrosnabzheniya v infokommunikatsionnykh sistemakh. Karelskij nauchnyj zhurnal. 2015. Vol. 11. No. 2. P. 115-120. [In Russian].

4. Khorolskij V. Y., Ershov A. B., Efanov A. V. Kolichestvennoe opredelenie i sravnitelnaya otsenka nadezhnosti ehnergeticheskikh massivov. Elektrotekhnika. 2017. No. 8. P. 19-22. [In Russian].

5. Talapko D. Telecom datacenter power infrastructure availability comparison of DC and AC UPS. International Telecommunications Energy Conference (INTELEC). $2012 . \quad$ P. 1-5. https://doi.org/10.1109/INTLEC.2012.6374509

6. Gotovych V., Nazarevych O., Shcherbak L. Mathematical modeling of the regular-mode electric power supply and electric power consumption processes of the organization. Scientific Journal of TNTU. 2018. Vol. 91. No. 3. P. 134-142. https://doi.org/10.33108/visnyk_tntu2018.03.134

7. Rasmussen N. Modelirovanie ehffektivnosti ehnergopotrebleniya v tsentrakh obrabotki dannykh. Zhurnal setevykh reshenij/LAN. 2007. No. 11. P. 40-47. [In Russian].

8. Abbasova T.S. Povyshenie ehnergeticheskoj ehffektivnosti tsentrov obrabotki dannykh dlya telekommunikatsionnykh sistem. Servis v Rossii i za rubezhom. 2009. No. 2. P. 1689-1699. [In Russian].

9. Saro L., Zanettin C., Božič V. Reliability Analysis and Calculations for Different Power System Architectures based on Modular UPS. 2018 IEEE International Telecommunications Energy Conference (INTELEC). 2018. P. 1-8. https://doi.org/10.1109/INTLEC.2018.8612341.

10. Wang C., Member S., Jain P. A Quantitative Comparison and Evaluation of 48V DC and 380V DC Distribution Systems for Datacenters. IEEE 36th International Telecommunications Energy Conference (INTELEC). 2014. P. 1-7. URL: https://doi.org/10.1109/INTLEC.2014.6972112.

11. Qi S., Sun W., Wu Y. Comparative Analysis on Different Architectures of Power Supply System for Data Center and Telecom Center. IEEE International Telecommunications Energy Conference (INTELEC). 2017. P. 26-29. https://doi.org/10.1109/INTLEC.2017.8211672.

12. Abbasova T.S. Energeticheskaya ehffektivnost sistem ehlektropitaniya dlya vysokoskorostnykh telekommunikatsionnykh sistem. Elektrotekhnicheskie i informatsionnye kompleksy i sistemy. 2009. Vol. 5. No. 2. P. 1-7. [In Russian].

13. Palamar M., Pasternak Y., Palamar A. Doslidzhennia dynamichnykh pokhybok systemy pretsyziinoho keruvannia antenoiu z asynkhronnym elektropryvodom. Visnyk TNTU. 2014. Vol. 76. No. 4. P. 164-173. [In Ukrainian].

14. Palamar A., Karpinskyy M., Vodovozov V. Design and implementation of a digital control and monitoring system for an AC/DC UPS. 7th International Conference-Workshop "Compatibility and Power Electronics" CPE 2011. Tallinn, Estonia. 2011. P. 173-177. URL: https://doi.org/10.1109/ CPE.2011.5942227.

15. Palamar A., Karpinskyy M. Control of an Uninterruptible Power Supply in a DC Microgrid System. 10th International Symposium Symposium "Topical Problems in the Field of Electrical and Power Engineering" and "Doctoral School of Energy and Geotechnology II". Pärnu, Estonia. 2011. P. 80-84.

\section{Список використаної літератури}

1. Andriychuk V., Filyuk Y. Autonomous power supply system for outdoor illumination of residential areas in the territory of Ukraine. Scientific Journal of TNTU. 2018. Vol. 89. No. 1. P. 113-121. https://doi.org/10.33108/visnyk_tntu2018.01.113

2. Григораш О. В., Денисенко Е. А., Чумак М. С. Синтез модульных систем бесперебойного электроснабжения повышенной надёжности. Политематический сетевой электронный научный журнал Кубанского государственного аграрного университета. 2015. № 4 (108). С. 1-14.

3. Дулепов Д. Е., Тюндина Т. Е. Качество и надежность электроснабжения в инфокоммуникационных системах. Карельский научный журнал. 2015. № 2 (11). С. 115-120.

4. Хорольский В. Я., Ершов А. Б., Ефанов А. В. Количественное определение и сравнительная оценка надежности энергетических массивов. Электротехника. 2017. № 8. С. 19-22.

5. Talapko D. Telecom datacenter power infrastructure availability comparison of DC and AC UPS. International Telecommunications Energy Conference (INTELEC). 2012. P. 1-5. https://doi.org/10.1109/INTLEC.2012.6374509

6. Gotovych V., Nazarevych O., Shcherbak L. Mathematical modeling of the regular-mode electric power supply and electric power consumption processes of the organization. Scientific Journal of TNTU. 2018. Vol. 91. No 3. P. 134-142. https://doi.org/10.33108/visnyk_tntu2018.03.134

7. Расмуссен Н. Моделирование эффективности энергопотребления в центрах обработки данных Журнал сетевых решений/LAN. 2007. № 11. C. 40-47. 
8. Аббасова Т.С. Повышение энергетической эффективности центров обработки данных для телекоммуникационных систем. Сервис в России и за рубежом. 2009. № 2. С. 1689-1699.

9. Saro L., Zanettin C., Božič V. Reliability Analysis and Calculations for Different Power System Architectures based on Modular UPS. 2018 IEEE International Telecommunications Energy Conference (INTELEC). 2018. P. 1-8. https://doi.org/10.1109/INTLEC.2018.8612341.

10. Wang C., Member S., Jain P. A Quantitative Comparison and Evaluation of 48V DC and 380V DC Distribution Systems for Datacenters. IEEE 36th International Telecommunications Energy Conference (INTELEC). 2014. P. 1-7. DOI: https://doi.org/10.1109/INTLEC.2014.6972112.

11. Qi S., Sun W., Wu Y. Comparative Analysis on Different Architectures of Power Supply System for Data Center and Telecom Center. IEEE International Telecommunications Energy Conference (INTELEC). 2017. P. 26-29. https://doi.org/10.1109/INTLEC.2017.8211672.

12. Аббасова Т. С. Энергетическая эффективность систем электропитания для высокоскоростных телекоммуникационных систем. Электротехнические и информационные комплексы и системы. 2009. № 2 (5). C. 1-7.

13. Паламар М., Пастернак Ю., Паламар А. Дослідження динамічних похибок системи прецизійного керування антеною $з$ асинхронним електроприводом. Вісник ТНТУ. 2014. № 4 (76). С. 164-173.

14. Palamar A., Karpinskyy M., Vodovozov V. Design and implementation of a digital control and monitoring system for an AC/DC UPS. 7th International Conference-Workshop «Compatibility and Power Electronics» CPE 2011. Tallinn, Estonia. 2011. P. 173-177. https://doi.org/10.1109/CPE.2011.5942227.

15. Palamar A., Karpinskyy M. Control of an Uninterruptible Power Supply in a DC Microgrid System. 10th International Symposium Symposium «Topical Problems in the Field of Electrical and Power Engineering» and «Doctoral School of Energy and Geotechnology II». Pärnu, Estonia. 2011. P. 80-84.

\title{
УДК 004.02:681.518:621.311
}

\section{МОДЕЛЮВАННЯ СИСТЕМИ КЕРУВАННЯ МОДУЛЬНИМ ДЖЕРЕЛОМ БЕЗПЕРЕБІЙНОГО ЖИВЛЕННЯ 3 ФУНКЦІЕЮ АДАПТИВНОГО РЕГУЛЮВАННЯ}

\author{
Андрій Паламар \\ Тернопільський начіональний технічний університет імені Івана Пулюя, \\ Тернопіль, Україна
}

\begin{abstract}
Резюме. Розглянуто питання імітаційного моделювання системи керування роботою випрямлячів модульного джерела безперебійного живлення постійного струму з метою підвищення його енергоефективності. Запропоновано алгоритм керуючої логіки для управління процесом перемикання силових модулів ДБЖ у режимі адаптивного регулювання потужності системи. Основна ідея методу полягає в реалізачії прочесу ввімкнення/вимкнення випрямлячів для досягнення оптимального значення коефіиієнта їх завантаженості та підтримання його рівня в певному заданому діапазоні. Наведено структурну схему системи керування модульного джерела безперебійного живлення, до складу якої крім центрального керуючого модуля введено блок керування випрямлячами, який відповідає за реалізацію процесу їх ввімкнення/вимкнення та здійснює контроль їх стану. Для дослідження ефективності розробленого алгоритму створено комп'ютерну модель для описування керуючої логіки управління випрямлячами. Для реалізачї імітаційної моделі використано програмне середовище візуального моделювання Simulink Matlab та математичний апарат бібліотеки компонентів Stateflow. Виконано тестування розробленої імітаційної моделі та наведено результати моделювання у вигляді осцилограм. Застосування розробленого алгоритму дозволило здійснювати регулювання коефіцієнта завантаженості модульного джерела безперебійного живлення в режимі реального часу в межах наперед заданого оптимального діапазону значень. Результати моделювання демонструють ефективність розробленої імітаційної моделі системи керування за різних значень вхідних електричних параметрів. Отримані результати використано при впровадженні розробленого алгоритму в реальній системі керування модульним джерелом безперебійного живлення постійного струму.
\end{abstract}

Ключові слова: система керування, джерело безперебійного живлення, імітаційне моделювання. 